\title{
LEITURA DA LEITURA: CARLOS DRUMMOND DE ANDRADE E ANA CRISTINA CESAR
}

RESUMO: A proposta de leitura dos poemas de Carlos Drummond de Andrade intitulados "Explicação" e "O sobrevivente" que ora se apresenta parte das anotações constantes em um exemplar de Reunião, coletânea de livros do poeta mineiro publicados até 1969, que pertenceu à também poeta Ana Cristina Cesar. Em tais notas mostra-se flagrante uma noção de poesia aliada à vida, muito pertinente às discussões que estavam sendo realizadas, então, por ocasião dos "novos poetas" da década 1970, e que se relaciona, por sua vez, com uma concepção de poesia, perceptível nos poemas selecionados, que se efetiva na busca, nunca completa, a que se lança o poeta.

PALAVRAS-CHAVE: Ana Cristina Cesar; Carlos Drummond de Andrade; Experiência; Poesia.

\section{Da releitura}

Ana Cristina Cesar, no exemplar que possuía de Reunião (1969), demonstra ter realizado leituras atentas dos poemas de Carlos Drummond de Andrade, inferência verificável pelos rastros sintomáticos que a poeta deixa grafados nas páginas do livro ${ }^{1}$.

\footnotetext{
* Doutoranda em Literatura pela Universidade Federal de Santa Catarina (bolsista CNPq), mestre em Literatura pela mesma instituição.

${ }^{1} \mathrm{O}$ exame de tais anotações realizado nesta pesquisa parte, por sua vez, da transcrição feita por Sílvia Cipullo em sua dissertação de mestrado: Cf. CIPULLO, S.M.F. Ana Cristina Cesar lê Drummond. Universidade Federal de Santa Catarina, agosto de 1994.
} 
É oportuno lembrar que Ana, no início da década de 1970, cursava licenciatura em letras na Pontifícia Universidade Católica do Rio de Janeiro. Portanto, “[...] de um lado, temos uma aluna de literatura que estuda detalhadamente um 'poeta oficial' e, de outro, notas de uma poeta que se alimenta de outros poetas para poder escrever, constituindo, em última instância, seu próprio eu poético" (CIPULLO, 1994, p.22).

O que interessa em maior grau nesta pesquisa são as anotações que parecem sugerir uma ideia de poesia aliada à experiência, consoante, portanto, a uma concepção de arte flagrante em certa dicção poética da década de 1970.

Característica dessa "nova poesia", a marca da "experiência imediata de vida dos poetas" seria tratada de forma às vezes ambígua e irônica. "O registro do cotidiano quase em estado bruto [...] revela os traços de um novo tipo de relação com a literatura, agora quase confundida com a vida” (HOLLANDA, 2004, p. 109) - ainda que não seja este um procedimento propriamente inovador.

Em Impressões de Viagem, Heloísa Buarque de Hollanda defende que a "mudança fundamental" dos "novíssimos" em relação ao binômio arte/vida será a valorização expressa do presente, do "aqui e agora". Por outro lado, também seria perceptível nessa nova poesia uma atitude anti-intelectualista, cuja recusa das "formas sérias do conhecimento" passaria a configurar um traço importante e crítico de uma experiência de "descrença em relação à universidade e ao rigor das linguagens técnicas, científicas e intelectuais". Para Heloísa, essa não seria apenas uma forma preguiçosa ou ingênua de representar o mundo, mas uma outra forma de pensá-lo, já que ambos aspectos, a valorização do momento e o que chamou de atitude anti-intelectualista, podem ser integrados como sinal de uma crítica mais ampla à ciência, à técnica e à noção de progresso (HOLLANDA, 2004, p. 111-112). 
Em 1976 Heloísa traz à tona o importante livro intitulado 26 Poetas Hoje e que motivaria, em agosto do mesmo ano, uma entrevista concedida à Revista Jose $e^{3}$. Dos poetas que compõem o livro e que participam do encontro promovido pela José estão Geraldo Eduardo Carneiro e Eudoro Augusto além, é claro, de Ana Cristina Cesar.

Como bem aponta Sebastião Uchoa Leite no início da entrevista, apesar de não ser perceptível uma proposta estética comum ao "grupo", mas sim uma "proposta existencial comum"4, é possível observar "uma anarquia, um escárnio", um "deboche propriamente literário” nos “novíssimos”, embora seja tal prática "um negócio já razoavelmente antigo”, como argumenta Luiz Costa Lima.

Ao longo da conversa algumas referências chamam a atenção. É o caso, por exemplo, da citação de Charles Olson ${ }^{5}$ e Robert Rauschenberg ${ }^{6}$.

2 Ao contrário de ser entendido enquanto um panorama da produção poética do período, Heloísa manifesta o desejo de que a antologia fosse vista, antes, como "a reunião de alguns dos resultados mais significativos de uma poesia que se anuncia já com grande força”. (HOLLANDA, 1976, p.10-11). Como bem afirma Maria Lúcia de Barros Camargo em sua tese sobre a poesia de Ana Cristina Cesar, a antologia organizada por Heloísa Buarque "adquiriu notoriedade como divulgadora da nova poesia dos anos 70" (2003, p.15). Dela participam "tanto integrantes de grupos já organizados como alguns poetas 'independentes', a exemplo de Ana Cristina Cesar (mas que mantinha relações com aqueles grupos, participando de encontros e discussões), Roberto Piva, Zulmira Ribeiro Tavares, Flávio Aguiar, Waly Sailormoon e, inclusive, Torquato Neto, falecido em 1972” (Ibid., p.20).

${ }^{3}$ Edição nº2, agosto de 1976.

${ }^{4}$ Apesar dos projetos editoriais comuns, a poesia de 1970, ou o que se convencionou chamar de "poesia marginal" é marcada, sobretudo, por diferenças e particularidades entre os autores, não podendo ser entendida enquanto um movimento: "[...] pode-se dizer que houve um fenômeno mais relacionado às questões de mercado do que a um projeto estético. [...] Parece que no caso da poesia dos anos 70, e mais especificamente em relação a essa que se convencionou chamar de marginal, há uma consciência da mudança a ser feita na linguagem, por oposição à vanguarda concretista. No entanto, parece ser mais forte o projeto existencial, uma atitude diante da vida e da arte". (CAMARGO, 2003, p. 41-42)

${ }^{5}$ Charles Olson ficou conhecido por cunhar o termo "pós-modernismo", que diria respeito a um mundo pósmoderno, um pós-Ocidente, posterior à Revolução Industrial O termo foi usado em manifesto de 1952, embora só tenha se popularizado na década de 1970. As técnicas desenvolvidas por Olson são observáveis em boa parte da poesia norte-americana mais recente, influenciando, inclusive, poetas como Allen Ginsberg, que também é citado na entrevista em questão.

${ }^{6}$ Artista vinculado ao expressionismo abstrato e cujas obras podem ser consideradas precursoras da pop art, dedicou-se, principalmente pelo combine painting, à criação de uma pintura composta não somente de massa pigmentária, mas incluindo também objetos. A pintura combinada de Rauschenberg tinha por objetivo a fusão do pictórico e do material, numa tentativa de privar a pintura de sua "aura". Rauschenberg afirmava não confiar em ideias, preferindo os materiais, pois estes o colocariam em confronto com o desconhecido. 
Quando Heloísa cita Olson ${ }^{7}$, o faz como apoio argumentativo à compreensão de uma poesia (daquela, por ocasião da publicação de 26 Poetas Hoje) enquanto texto traçado como tensão entre objetos e emoções: "A ideia”, diz ela, "é acompanhar a emoção e não controlá-la. A experiência de estar fazendo poesia e vivendo a poesia é, muitas vezes, prioritária à elaboração poética".

Robert Rauschenberg 8 , por sua vez, é citado por Geraldo Carneiro pelo trabalho artístico que realiza na brecha que existe entre vida e arte: "Isso é muito mais que usar a própria vida como matéria-prima".

Pode-se pensar que as referências a Olson e Rauschenberg salientam uma concepção de poesia (e de arte, em última análise) que retoma, em certa medida, a tônica modernista de $1922^{9}$, principalmente no tratamento que é dado ao coloquial, mas que sobrepõe a subjetividade, ao contrário de Oswald, Drummond e Bandeira (o de Libertinagem, assinalese), cuja objetividade seria mais forte. Para Uchoa Leite ${ }^{10}$ essa "maior subjetividade ao tratar

${ }^{7}$ Jorge Wanderley pergunta: "Heloísa assinala na introdução um afunilamento de caminhos entre poesia e vida. Isso não implicará uma certa aceitação da vida como ela está?” Ao que Heloísa responde, citando Olson: "Me fez lembrar Olson quando diz que a poesia é um campo de ação. O texto é traçado como tensão entre objetos e emoções. A ideia é acompanhar a emoção e não controlá-la. A experiência de estar fazendo poesia e vivendo a poesia é muitas vezes prioritária à elaboração poética. Há mesmo uma certa conclamação para que todos e qualquer um faça poesia. É um impulso apaixonado e vitalista".

8 "Me parece que a matéria-prima dos poetas mais consequentes não é vivencial. É uma poesia bem diferente da poesia que trabalha com ícones de uma linguagem anterior a ela, associada à linguagem literária. [...] A matériaprima está mais próxima da pop art no sentido plástico, mesmo, não no sentido corrente. Gosto muito de uma frase de Rauschenberg: trabalho no espaço que existe entre a vida e a arte, na brecha que existe entre a vida e a arte. Isso é muito mais que usar como matéria-prima a própria vida".

${ }^{9}$ No livro Impressões de viagem, Heloísa comenta brevemente o trecho constante na introdução da antologia 26 poetas hoje, em que afirma haver nos "novíssimos" uma retomada do coloquial de 1922: "Para Oswald de Andrade, [...] a interferência do coloquial no literário era, sem dúvida, um procedimento ainda, e por excelência, literário". Já para os novíssimos, "é poetização de uma vivência, é a poetização da experiência do cotidiano e não o cotidiano poetizado. É a arte de captar situações no momento em que estão acontecendo, sentimentos que estão sendo vividos e experimentados e fazer com que o próprio processo de elaboração do poema reforce esse caráter de momentaneidade. E isso não pode e não deve ser reduzido apenas a um artifício literário. Nesse gesto no qual o trabalho, a ciência, o progresso e o futuro deixam de ser valores fundamentais, o cotidiano passa a ser arte" (2004, p.112).

${ }^{10}$ Logo no início, afirma: "Heloísa, na introdução, fala de uma retomada de 22. Acho que essa retomada é relativa, pois me parece que a distinção é que a poesia de Oswald, de Drummond e de um certo Bandeira de 'Libertinagem' 
da realidade" constituiria um problema, já que o poeta, ao optar pela negação da imaginação poética, ficaria preso aos seus próprios fantasmas, sem alcançar o nível simbólico.

Não cabe aqui discutir em que medida a poesia de Ana Cristina opera na contramão do estabelecido principalmente por Uchoa Leite ao criar, por exemplo, uma vida literária a ser confessada de maneira ficcional, pelo desnude de uma escrita de si que se confunde entre o vivido e o inventado, entre a memória e a desrealidade ${ }^{11}$; mas o fato é que as notas de leitura que Ana realiza exemplar de Reunião parecem sugerir uma concepção de poesia muito próxima da noção defendida no período, como bem demonstram as anotações utilizadas no recorte desta pesquisa.

\section{Explicação primeira}

Apesar de ter apenas seus dois últimos versos finais grifados por inteiro no exemplar de Ana, o poema "Explicação" chama a atenção por si só:

Meu verso é minha consolação.

Meu verso é minha cachaça. Todo o mundo tem sua cachaça.

Para beber, copo de cristal, canequinha de fôlha-de-flandres, folha de taioba, pouco importa: tudo serve.

Para louvar a Deus como para aliviar o peito, queixar o desprezo da morena, cantar minha vida e trabalhos é que faço meu verso. E meu verso me agrada.

Meu verso me agrada sempre...

Ele às vezes tem o ar sem-vergonha de quem vai dar uma cambalhota, mas não é para o público, é para mim mesmo essa cambalhota. Eu bem me entendo.

Não sou alegre. Sou até muito triste.

é uma poesia voltada para o coloquial mas com um sentido de objetividade muito forte enquanto que nesta, a do grupo de vocês é a tônica da subjetividade que é forte".

${ }^{11}$ Contrário à crítica formulada por Uchoa Leite aos novos poetas, resgata-se o comentário de Flora Süssekind acerca da poesia de Ana Cristina Cesar em Literatura e vida literária quando afirma que a subjetividade por ela manejada "é antes de tudo literária, em sentido pleno, construída esteticamente e construída na literatura” (1985, p.78). 
A culpa é da sombra das bananeiras de meu país, esta sombra mole, preguiçosa

Há dias em que ando na rua de olhos baixos

para que ninguém desconfie, ninguém perceba

que passei a noite inteira chorando.

Estou no cinema vendo fita de Hoot Gibson, de repente ouço a voz de uma viola...

saio desanimado.

Ah, ser filho de fazendeiro!

À beira do São Francisco, do Paraíba ou de qualquer córrego vagabundo, é sempre a mesma sen-si-bi-li-da-de.

E a gente viajando na pátria sente saudades da pátria.

Aquela casa de nove andares comerciais

é muito interessante.

A casa colonial da fazenda também era...

No elevador penso na roça,

na roça penso no elevador.

Quem me fez assim foi minha gente e minha terra

e eu gosto bem de ter nascido com essa tara.

Para mim, de todas as burrices a maior é suspirar pela Europa.

A Europa é uma cidade muito velha onde só fazem caso de dinheiro

e tem umas atrizes de pernas adjetivas que passam a perna na gente.

O francês, o italiano, o judeu falam uma língua de farrapos.

Aqui ao menos a gente sabe que tudo é uma canalha só,

lê o seu jornal, mete a língua no governo,

queixa-se da vida (a vida está tão cara)

e no fim dá certo.

Se meu verso não deu certo, foi seu ouvido que entortou.

Eu não disse ao senhor que não sou senão poeta?

"Explicação" integrava, originalmente, Minha terra tem palmeiras, caderno de poemas que Drummond nunca chegou a publicar $^{12}$, mas que foram reunidos, em sua maioria, no livro de estreia, Alguma poesia.

\footnotetext{
${ }^{12}$ Em carta do dia 3 de junho de 1926, Drummond envia a Mário cópia do que ele chama "caderno de versos": "Foi o que pude arranjar como papel e como obra. [...] De sorte que este caderno não contém tudo. Mas contém o melhor (Minha terra tem palmeiras, esboço de livro que peço licença para te dedicar). A primeira parte é só por amizade que te comunico. Sei que são versos inferiores, até penumbristas; só valeu como documentação. Tem muita lagrimazinha besta e muito estrepe sentimental nesses papeis. Você dê o devido desconto e me queira sempre bem" (ANDRADE; ANDRADE, 2002, p.220).
} 
Apesar de ser até pouco comentado quando em comparação ao famoso "Poema de sete faces", "Explicação" não passou despercebido do mestre e amigo Mário de Andrade, que em carta resposta do dia $1^{\circ}$ de agosto de 1926, em meio a algumas críticas pontuais e apontamentos curiosos, comenta: “peso-pesado. Mesma coisa que 'Eu protesto' porém sem besteiras e muito mais melhor. Forte mesmo. Eu botaria isso no começo do livro que nem Prefácio. E datava o poema, assim como datava as partes do livro" (ANDRADE; ANDRADE, 2002, p. 233).

"Explicação", como adianta o próprio título, funciona como uma espécie de poética em que o sujeito lírico tenta, de fato, explicar ao leitor por que afinal escreve, podendo, nesse sentido, ser até mesmo aproximado ao estilo do "Prefácio interessantíssimo", do próprio Mário.

John Gledson (2003, p.83) defende que esse poema, a exemplo de "Bucólica no caminho de pontal" e "Convite ao suicídio", revelam uma influência de Mário (principalmente o de Paulicéia) na poética de Drummond, no sentido de que "o eu, apesar de claramente derivar do poeta entusiástico e algo maníaco de Paulicéia, está ao mesmo tempo menos enfatizado e mais autobiográfico do que Mário jamais foi naquele livro”.

A linha autobiográfica sugerida pelo crítico inglês é entendida nesta pesquisa a partir do explícito entrelaçamento de arte e vida, especialmente expresso nos versos de "Explicação", o que denota, em larga medida, a preocupação de encarar em níveis equitativos tanto "a superfície do comportamento cotidiano", quanto "a profundidade da obra de arte" na compreensão da atividade do escritor, entendimento observado principalmente nos vanguardistas da primeira metade do século, para os quais "Vida \& Arte se entrelaçam", como bem apontou Silviano Santiago em prefácio ao livro de correspondências dos dois Andrades (ANDRADE; ANDRADE, 2002, p.10).

Nos primeiros versos, o eu lírico aproxima poesia da cachaça, índice de escapismo na vida contemporânea que, não raro, se torna vício a quem dela prove:

Meu verso é minha consolação.

Meu verso é minha cachaça. Todo o mundo tem sua cachaça. 
O primeiro verso, em nove sílabas, e o segundo, podendo ser lido com cisão rítmica marcada pelo ponto final que subdivide as duas orações, é construído a partir de um verso de sete e oito sílabas, respectivamente. Aliás, esse recurso é aproveitado ainda algumas vezes nos versos seguintes deste poema.

Como se pode notar, não se trata de um poema escrito em verso livre; o uso do verso polimétrico e mesmo a consciência da cisão rítmica em vários deles denota domínio da técnica por parte do poeta, que escreve o poema em questão muito provavelmente nos seus anos de juventude ainda.

Note-se que a introdução comum aos dois versos, "Meu verso é minha", pode ser lida por um marcado ritmo iâmbico, o que reforça a afirmação expressa; a repetição dos pronomes possessivos, marca que é também assinalada por Ana em sua leitura, contribui para o efeito, que nos leva a imaginar que o sujeito lírico do poema, tal qual um homem que possui um vício, sente a necessidade, em rompantes que não raro lhe ocorrem, de justificar, ou reafirmando o próprio poema, de "explicar" sua condição de dependência, atenuando-a com uma constatação geral: "Todo o mundo tem sua cachaça". Também a profusão da vogal “o” nessa última oração dificulta até mesmo a escolha de uma vogal de apoio, já que a última tônica (única indiscutivelmente aberta) aparece somente em "cachaça", conferindo um tom fechado ao verso, como se numa lamúria interior o sujeito lírico se dirigisse para dentro de si, tentando se convencer do que afirmara.

Na mesma estrofe são elencados os meios de uso: "copo de cristal", "canequinha de folha-de-flandres", "folha de taioba". Assim como o material de que se vale a poesia, “pouco importa: tudo serve”, pois que não há "assuntos poéticos e não-poéticos. Qualquer assunto vale o que vale o seu aproveitador ${ }^{13}$ " (ANDRADE; ANDRADE, 2002, p.121).

Vício e consolação: "todo mundo tem sua cachaça”. A do poeta é o (re) criar vida em verso, ritmo, imagem. Assim como "os meios de uso" são vários, os motivos também:

13 Trecho de carta que Drummond envia a Mário em 20 de maio de 1925. 
Para louvar a Deus como para aliviar o peito

queixar o desprezo da morena, cantar minha vida e trabalhos

O sujeito lírico contrasta seu motivo, ora sublime ("Para louvar a Deus" e "cantar minha vida e trabalhos"), em que há predominância de vogais abertas ("louvar", "cantar", "trabalhos"); ora baixo ("aliviar o peito", "queixar o desprezo da morena”), que trazem a predominância de vogais fechadas ("peito", "desprezo", "morena”).

A linha autobiográfica proposta por Gledson parece perigosa, pois, ao passo que o sujeito do poema nos apresenta dados concretos da vida cotidiana (do possível eu por trás do eu), o faz também de forma irônica, já que o poema não é, propriamente, uma exposição daquela personalidade, mas justamente uma afirmação de sua incomunicabilidade:

Ele às vezes tem o ar sem-vergonha de quem vai dar uma cambalhota, mas não é para o público, é para mim mesmo essa cambalhota.

O uso irônico do detalhe autobiográfico, portanto, neutraliza qualquer possibilidade de identificação. Sentimos a presença do poeta, acima de tudo, na consciência do choque entre o velho e o novo (algo de que também Mário é muito consciente): "Velho/novo: Antropofagia, tropicália”, como mesmo nos atesta a anotação de Ana Cristina Cesar na altura dos últimos versos da quarta estrofe do poema.

Esse contraste entre a tradição e o novo, entre moderno e província, também é destacado pela leitura de Ana em outros versos do poema, como é o caso do trecho a seguir:

Estou no cinema vendo fita de Hoot Gibson, de repente ouço a voz de uma viola...

Em seu exemplar, Ana grifa o vocábulo “viola” (acrescido da palavra “divisão”), aludindo à oposição indicada no verso anterior pelo cinema, índice de modernidade.

Nos versos acima ocorre até mesmo um desalinho rítmico de um verso a outro, ou melhor, uma sintonia de ritmo antes desalinhada: no primeiro, verso em treze silabadas, o ritmo é aleatório, como se narrasse um fato qualquer (a acentuação recai na segunda, quinta, 
nona e décima terceira sílabas); mas o sentimentalismo do sujeito lírico retorna quando ouve tocar a viola, que mobiliza seu sentimento de saudade: nesse verso, eneassílabo, a terceira, a sexta e a nona sílabas são acentuadas, conferindo um ritmo anapéstico ao verso.

$\mathrm{Na}$ altura dos versos 24 e 26, o mesmo contraste entre moderno e antigo, situado anteriormente entre as figuras do cinema e da viola, ocorre com "nove andares" e "casa colonial":

Aquela casa de nove andares comerciais

é muito interessante.

A casa colonial da fazenda também era...

Nessas duas ocasiões, a marca da sensibilidade que faz o sujeito lírico sentir "saudades da pátria" mesmo "viajando na pátria”, é também evidenciada pelo expressivo uso de reticências no fim de verso.

É sempre a mesma "sensibilidade", que o sujeito lírico faz questão de evidenciar graficamente no poema, que interrompe até mesmo o ritmo do verso:

$$
\text { é sempre a mesma sen-si-bi-li-da-de. }
$$

Note-se que o verso destacado acima pode ser lido pelo ritmo iâmbico, inicialmente, até ser desarticulado pela "sensibilidade".

O traço do "sensível”, que Davi Arrigucci Jr. (2002) chamou de caráter reflexivo da poesia de Drummond, não passou despercebido de Manuel Bandeira e Mário de Andrade.

Para o Bardo, que é referido pelo poeta mineiro inclusive como aquele com quem aprendeu a fazer versos ${ }^{14}$, a "perfeição técnica" em Drummond "não resulta, como em Guilherme de Almeida, do gosto e trabalho do artista, mas da fidelidade do poeta ao movimento lírico da sensibilidade ${ }^{15}$ ".

\footnotetext{
${ }^{14}$ Drummond, em entrevista a Pedro Bloch para a revista Manchete em junho de 1963, relata: "Bandeira é mais velho do que eu. Aprendi a fazer versos através dos versos dele. É um homem excepcional. [...] Ele é uma espécie de arco-íris na poesia brasileira. Abrange todas as experiências..." (ANDRADE, 2011, p.84).

${ }^{15}$ Em resenha do dia 24 de maio de 1930 para o Diário Nacional (e republicada no jornal A Província, de Recife, em 25 de maio de 1930, dia seguinte ao da publicação no Rio de Janeiro). A resenha é sobre o livro de estreia de 
Semelhante constatação é realizada por Mário em julho de 1930 quando escreve a Drummond uma extensa e importante carta na qual tece alguns comentários a respeito do então recém-publicado Alguma poesia. Aproximando comparativamente Drummond a Manuel Bandeira, Mário comenta ser justamente a naturalidade de dicção, "também perfeitamente espontânea", o elemento técnico importante em seu fazer poético: "Você é simples sem artefação nenhuma nos melhores momentos seus. Deixa a frase correr e ela é um regatinho. Raro o efeito" (ANDRADE; ANDRADE,2002, p.389).

Assim como Bandeira, Mário compara também Drummond a Guilherme de Almeida, mas com outro intuito:

Como rítmica você é riquíssimo, e a riqueza de você diverge sensivelmente da de Guilherme de Almeida e, a meu ver, em valorização maior da de você porque a do Gui, embora muito mais rica e perfeita, é duma ordem exclusivamente artística, de artesão, ao passo que a de você é duma naturalidade, duma liberdade perfeitamente espontânea e por isso provando maior força interior. Você é fatalizadamente um poeta - ao passo que o Gui é poeta porque quer e quando quer (ANDRADE; ANDRADE, 2002, p.388-389).

Apesar de valorizar a sensibilidade propriamente drummondiana que o caracterizaria fatalmente como poeta, Mário não deixa de situar a importante divergência de "riqueza poética" entre o mineiro e Guilherme de Almeida, o qual, ao lado de Ronald de Carvalho, figura como nome recorrente nas cartas de Mário, ambos como referências do almejado "equilíbrio entre lirismo e faculdade intelectual"16. Em carta a Drummond em 16 de outubro de 1925, afirma:

Drummond, publicado naquele mesmo ano. No texto, Bandeira traça rapidamente o percurso do até então anônimo Carlos Drummond de Andrade: “Agora o poeta compareceu em livro. E esse livro se nos revela, logo ao primeiro exame, um dos mais puros e belos de nossa poesia. Não pode haver dúvidas: Carlos Drummond de Andrade é um dos grandes poetas do Brasil. Grande pelo fundo de sensibilidade e lirismo como grande pela técnica impecável de seus poemas".

${ }^{16}$ A mesma discussão é levantada em carta a Prudente de Moraes, neto, em 3 de outubro de 1925, dias antes: "No Losango Cáqui [...] numerei os poemas em que não tinha "a intenção de poema" como falei no Prefácio. Essa história da intenção de fazer uma poesia é uma coisa muito importante sob o ponto de vista Arte, fazer de deveras arte. Convido você a meditar muito nisso. Tem sido uma das preocupações grandes da minha vida. 
Quanto à poesia dele [referindo-se à Pedro Nava] não sei não ainda porém me parece que será o mais batuta de vocês todos. Como poeta. Você tem elemento lírico mais sutil mais intenso mesmo, é difícil de explicar assim de supetão em carta e não estou pra fazer já artigo sobre vocês, quero esperar mais um pouco, porém você me parece mais perto do Manuel, Nava me parece mais perto do Guilherme e do Ronald. A gente pode notar mesmo na poesia dele alguma influência ainda do Gui [Guilherme de Almeida], porém isso não tem importância e passará na certa, acho mesmo que influências pra quem tem valor é boa escola, não faz mal nenhum e é aproveitável. Ora o que distingue Ronald e Guilherme é que são mais poetas, têm mais equilíbrio entre o lirismo e a faculdade intelectual. Criam melhor que nós, me parece. Em Nava se dá o mesmo (ANDRADE; ANDRADE, 2002, p. 153-154, grifos meus).

Quando são examinadas as relações entre Mário e Drummond, principalmente pelas cartas trocadas entre ambos, fica evidente que a concepção do poeta mineiro em torno da esfera de criação literária, em especial, lírica, revela-se sensivelmente divergente do psicologismo de Mário, por exemplo, para o qual o lirismo deveria estar submetido, necessariamente, à faculdade intelectual ${ }^{17}$.

A "intenção do poema", constrói o poema fechado [...]. É mais arte que esse sensacionismo verdadeiramente primitivistico como essência em que toda a gente modernista caiu mais ou menos. Principalmente os cuja criação vai de dentro pra fora, intimistas, os que se preocupam mais com a sensação que com a causa da sensação, Manuel, Ribeiro Couto eu muitas vezes. Raríssimamente Ronald e Guilherme, naturezas artísticas mais bem construídas e completas. Falo natureza artística no sentido de equilíbrio das faculdades líricas e construtivas. Em Manuel por exemplo, que é o mais cheio de lirismo da minha geração [...] tem um desequilíbrio evidente entre o lírico e o poeta. [...] Todos os últimos poemas dele, desde o Ritmo Dissoluto [...] são fragmentos do lirismo constante da vida". (ANDRADE, 1985, p.119-120, grifos meus)".

${ }^{17}$ Apesar da noção de lirismo em Mário sugerir a impressão de ser tomada pelo escritor como um objeto de construção contínua e reconfiguração constante, há que se reconhecer que durante boa parte de sua produção foi mantido um entendimento de poesia que separava a inspiração, de um lado, e, do outro, a faculdade intelectual. No livro A sereia e o desconfiado Roberto Schwarz chega mesmo a enumerar três etapas na conceituação do "lirismo" formuladas por Mário ao longo de sua trajetória intelectual: "1 - momento individualista, poesia = grafia do subconsciente (lirismo), com um mínimo de interferência técnica; 2 - momento anti-individualista; poesia = grafia do subconsciente transformado em arte e tornado socialmente significativo pela interferência técnica; o lirismo individual pode mesmo desaparecer em favor de uma fonte de emoção coletiva, o folclore; a valorização está toda no preparo técnico e cultural que permitirá a realização da tarefa nacionalista; 3 - superação dos momentos anteriores, que desponta no conceito de técnica pessoal, em que um lirismo específico (subconsciente individual) encontra uma técnica (nível consciente) capaz de realizá-lo no plano do significado geral” (1981, p.15). 
Apesar de entender a origem do movimento lírico num "eu profundo"18, Mário defende que tal instância da criação poética estaria (ou deveria estar) submetida à faculdade intelectual. A intelectualidade poética, nesses termos, fica evidente em carta a Drummond, de 18 de fevereiro de 1926, na qual confessa: "estou cada vez mais convicto que carece botar inteligência (sentida) na poesia. Meus poemas são cada vez mais pensados" (ANDRADE; ANDRADE, 2002, p.194, grifo do autor).

Drummond, pelo contrário, sempre foi poeta antes de tudo, para quem as fórmulas "matemáticas" propostas por Mário do tipo "lirismo + crítica + palavra"19 teriam pouco significado. Se Mário constatava em 1926 que seus poemas eram cada vez mais pensados, Drummond reconhecia em 1985, no saldo de toda sua obra, que não sabia fazer "poesia pensada". Com aquela modéstia irritante que lhe era peculiar, admitia miúdo: "não tenho capacidade para isso" 20 .

Mesmo a dificuldade em exercer sua capacidade crítica na prosa, por exemplo, diversas vezes expressa por Drummond, pode ser lida nesse traço de sensibilidade pungente. Para Mário, nos artigos do então iniciante Drummond era perceptível "pouca crítica e poucas observações" 21 . O amigo então o aconselha: "Ame vive chore em versos. Na prosa, na prosa crítica: ensine", a exemplo de Baudelaire, "mais crítico que criador". Mário insiste:

18 “[...] A impulsão lírica é livre, independe de nós, independe da nossa inteligência. Pode nascer de uma réstia de cebolas como de um amor perdido. [...] Papini considera mesmo como verdadeiro criador aquele que independe do silêncio, da boa almofada e larga secretária para escrever seu poema genial. [...] Todos os assuntos são vitais. Não há temas poéticos. Não há épocas poéticas. [...] O que realmente existe é o subconsciente enviando à inteligência telegramas e mais telegramas [...]. É o leitor que se deve elevar à sensibilidade do poeta não é o poeta que se deve baixar à sensibilidade do leitor. Pois este que traduza o telegrama" (ANDRADE, 2013, p.240-241).

19 "Lirismo puro + Crítica + Palavra $=$ Poesia. Dei-vos a receita.... Não falei na proporção dos ingredientes. Será: máximo de lirismo e máximo de crítica para adquirir o máximo de expressão. Daí ter escrito Dermée: 'O poeta é uma alma ardente, conduzida por uma cabeça fria”' (ANDRADE, 2013, p.238). A fórmula pode ser encontrada no livro A escrava que não é Isaura, publicado em 1924, "o primeiro que se publica no Brasil sobre poesia moderna", segundo Prudente de Moraes, neto em ensaio crítico sobre o livro, na revista Estética, no 3, 1925.

${ }^{20}$ Trata-se da entrevista concedida a Humberto Werneck para a revista Istoé em abril de 1985: "Não costumo escrever sem emoção. Podem achar que a minha poesia é demasiado fácil, demasiado assim, lacrimogênea; eu produzo emoção, eu quero comover, mas a realidade é que eu não sei fazer poesia pensada, não tenho capacidade para isso. (ANDRADE, 2011, p.21)

${ }^{21}$ Em carta sem data (1925) (ANDRADE; ANDRADE, 2002, p.114). 
"A criação dele é crítica. Provém dum contato de ideias de que ele tira um juízo, esse juízo é a inspiração dele”.

Drummond, em contrapartida, afirma ser "a negação da crítica”, e ter muito mais confiança nos seus versos ainda imperfeitos que nos seus artigos mais trabalhados ${ }^{22}$, ("Nunca me presumi crítico, você sabe, mas me presumo extremamente sensível à poesia" ${ }^{23}$ ), argumentando não ser artista, apenas poeta ${ }^{24}$ : "confesso que sou de uma pobreza crítica incomensurável, mas tenho uma sensibilidade exagerada por demais”.

É interessante notar como a própria postura do poeta em relação a essa sensibilidade foi afetada, em grande medida, pelo psicologismo de Mário.

Drummond, que não se definia como "poeta no sentido clássico ou erudito da palavra - o que obedece a um programa, observa as regras e procura renovar" (nunca tive essa pretensão") entendia sua própria poesia como um "desabafo" resultante do sentimento de inconformidade com o mundo ("Ela contém também (e muito), coisas irônicas, não poéticas" 25 ) e concebia o ato de fazer poesia como algo intrínseco à experiência que a arte lhe promove ("Procurei apenas tirar de mim o resultado, em palavras, de uma emoção que sinto naturalmente, ou por provocação externa"26). Prova cabal, para ele, de sua condição de "não poeta" ou de mau cultor da poesia, como afirma em outra ocasião. Em seu relato, a própria inserção de "coisas irônicas", ao lado de coisas "não poéticas" ajuda a

${ }^{22}$ Carta de Drummond a Mário em março de 1925 (Ibid., p.107).

${ }^{23}$ Trecho de carta que Drummond escreve a Mário no dia 2 de janeiro de 1928, em que manifesta a intenção de fazer uma nota sobre o Clã do Jabuti (Ibid, p.307).

24 "Estou cada vez mais convencido de que artista é uma coisa e poeta é outra", carta de 31 de janeiro de 1926 (Ibid., p. 188). Em relação a essa verdadeira "ojeriza crítica” de Drummond, Cf. poema "Exorcismo", inserido em Discurso de primavera.

${ }^{25}$ Em entrevista concedida a Pedro Bloch para a revista Manchete em junho de 1963, Drummond afirma acreditar ser o "poeta verdadeiro" aquele que "precisa de aprendizado, de uma adequação da própria vida". Colocando-se (ele, Drummond) aquém de tal concepção, assume ter feito poesia como o resultado de "um desabafo, da inconformidade com o mundo": "Ela contém também (e muito), coisas irônicas, não poéticas. O poeta verdadeiro não é como eu, de formação irregular. É como um Dante, que tem uma mensagem imensa a viver".

26 "Não sou capaz de fazer poema a frio, como se resolvesse um problema de matemática. Há um condicionamento, uma espécie de preparação determinada pelo tema”. Em entrevista a Fernando Sabino, publicada no Jornal do Brasil em 22 de julho de 1974. 
salientar essa noção, pois reforça uma aparente necessidade de correção do caráter de excessiva sensibilidade.

Em entrevista a Zuenir Ventura para a revista Veja em 19 de novembro de 1980, quando perguntado se tinha realmente consciência da dimensão de sua obra, Drummond responde:

Acho minha obra uma obra falha, uma obra que podia ser melhor. Ela não teve um desenvolvimento assim consciente, lógico. Fui levado pela intuição e pelo instinto, pelas emoções do momento. Não creio muito na validade dessa obra. Acho o seguinte: como sou um homem do meu tempo, exprimi paixões e emoções do meu tempo, e isso naturalmente tocou as pessoas. [...] Ao escrever poesia, o que eu procurei fazer foi resolver os problemas internos meus, problemas de ascendência, problemas genéticos, problemas de natureza psicológica, de inadaptação ao mundo, como ele existia. Foi a minha autoterapia (ANDRADE, 2011, p.120, grifos meus).

Fica evidente uma concepção de poesia atrelada à nudez de uma quase confissão.

Declaração semelhante é também perceptível em entrevista que concede a Carlos Menezes para o jornal O Globo em 1979. Quando indagado a respeito do momento em sua carreira em que se sentiu mais próximo de seus poemas, responde:

Sempre me identifiquei com os meus poemas. Nem compreendo que isso deixasse de acontecer. Se não sou obrigado a escrever, se escrevo por meu gosto e vontade, tenho que me colocar por inteiro naquilo que escrevo. Fazer poesia é uma forma de confissão, de nudez. Se não for assim, será mera brincadeira ou mistificação (ANDRADE, 2011, p.101).

A mesma concepção fica evidente em carta enviada a Alceu, datada de $1^{\circ}$ de junho de 1931:

Literariamente, eu supus a princípio que devia orientar-me na prosa, que era em mim apenas o plágio de autores brasileiros insignificantes. Com o advento do modernismo fiz poesia e nela me fixei, como sendo a minha verdadeira expressão literária. Com o tempo, verifiquei que meus versos são apenas a transposição de estados íntimos 
quase sempre dolorosos, e hoje o que e faço é só isso, apenas isso: confissão direta, ou quase, de mágoas, desvarios e desejos não realizados, reflexo dos fatos da minha vida sentimental. Quase não posso publicar esses versos porque isso equivaleria a me mostrar nu no meio da rua (ANDRADE; LIMA, 2015, p.104).

Ainda que em alguns momentos Drummond esteja se referindo propriamente à concepção de sua obra como um todo (que segundo ele teria acontecido fora de um programa “consciente”), fica nítida uma ideia de poesia (a sua) que beira quase ao valor negativo, de caráter muitas vezes pejorativo, sem desenvolvimento lógico e na qual a sensibilidade ou a transposição do estado emocional se dariam pelo excesso.

Essa postura fica evidente pela clara adjetivação negativa da dimensão essencialmente lírica de seu processo de escritura (poesia como "desabafo"; possuidora de "coisas irônicas, não poéticas"; poesia "falha", “irregular", que não teve um desenvolvimento "consciente", "lógico"; poesia guiada pela "intuição", pelo "instinto", pelas "emoções"; poesia como "forma de confissão", de "nudez”), que merecia ser "corrigido" ou controlado por algum recurso apreciado no meio modernista da época, para não cair em poesia sentimentaloide.

E para resgatar o poema, "Explicação" não parece intentar cumprir a função semântica à que se refere o próprio título? Numa tentativa de explicar essa sensibilidade em demasia, que o faz sentir nostalgia da "pátria", ora da "roça", ora do "elevador", que o faz olhar de outra forma para a vida e o cotidiano, "corrige", pela ironia e pelo humor, o traço pungente dessa "sensibilidade em demasia"?

Nesse sentido, a própria aproximação entre poesia e cachaça escolhida pelo poeta é fatalmente intencional: pelo verso, funcionando como uma válvula de escape, a ele é permitido transbordar sua sensibilidade reflexiva de diversas formas e sob diversas justificativas. Pois como "explicam”, para retomar o próprio título, os grifos de Ana nos versos finais do poema: 
Contudo, não se pode deixar de notar que o lirismo drummondiano não se reduz ao que chamamos aqui de traço do sensível. Como mesmo sustenta Davi Arrigucci Jr., que trata especialmente da questão no livro $O$ coração partido ${ }^{27}$, a sensibilidade propriamente drummondiana encontra no "sentimento" sua principal forma de expressão, mas não se resume a ele: "Seu lirismo, sem prejuízo da mais alta qualidade, nunca foi puro, mas mesclado de drama e pensamento" (ARRIGUCCI JR., 2005, p.16).

Nesse sentido, a leitura de Arrigucci diverge substancialmente da visão que Mário de Andrade faz da obra de Drummond, especialmente de seu aspecto "sensível", do lirismo descomedido, ou do que o próprio Mário chama de "naturalidade de dicção". Davi entende o lirismo drummondiano por um complexo sistema reflexivo que a lírica assume:

É que o pensamento desempenha um papel decisivo no mais íntimo dela, pois define a atitude básica do sujeito lírico, interferindo na relação que este mantém com o mundo exterior, ao mesmo tempo que cava mais fundo na própria subjetividade: o resultado desse processo é o adensamento desse lirismo pelo esforço meditativo, que casa um esquema de ideias à expressão dos sentimentos (ARRIGUCCI, 2005, p.16).

É sabido que esse "modo de poetar" que une sentimento e reflexão tem origem romântica ${ }^{28}$, mas é preciso entender o modo particular como Drummond tratou essa herança, responsável, em certa medida, pela originalidade moderna e boa parte dos conflitos específicos de sua poesia.

\footnotetext{
${ }^{27}$ A leitura de Davi desvincula a obra de Drummond de um entendimento seccionado em fases, como o faz a crítica tradicional, que subdivide os livros em agrupamentos histórico-temporais em que seria perceptível uma gradação contrastiva de estilos, de "humores" e uma possível diferença no modo de representar a realidade. Para Arrigucci, "as coisas não são bem assim". O crítico defende que essa oposição radical nunca existiu, assim como nunca aconteceu, em termos dilemáticos, aquela opção, inventada depois pela crítica, entre "um pretenso formalismo e a participação social referida a fatos exteriores, sociais e políticos, sobretudo nos anos 30 e 40 [...]" (ARRIGUCCI JR., 2005, p.18). Quando a leitura se aferra a fatos históricos pode conduzir a meros equívocos, pois "desde o começo a poesia de Drummond trouxe em si mesma o fermento da superação dos problemas que jamais deixou de incorporar, absorvendo nas camadas profundas a experiência histórica, que não se confunde necessariamente com os eventos de fora" (Ibid., p.18).

${ }^{28}$ Conforme observou Walter Benjamin em $O$ conceito de crítica de arte no romantismo alemão, a reflexão é o tipo de pensamento mais frequente nos primeiros românticos, que nela fundaram suas principais concepções, como a dos fragmentos de Friedrich Schlegel e de Novalis.
} 
Ao contrário dos românticos, em Drummond, o sentimento traz consigo a contradição. Sua grandeza poética, especialmente nesse complexo sistema pelo qual se organiza seu lirismo particular, residira, então, no modo como a reflexão, "que espelha na consciência o giro do pensamento refletindo-se a si mesmo", se une ao sentimento e à sua expressão poética, "determinando a configuração formal do poema, num mundo muito diferente daquele dos primeiros românticos e da poesia meditativa que inventaram" (ARRIGUCCI, 2005, p.16).

Pode-se mesmo afirmar que no lirismo drummondiano opera-se a passagem de uma lógica conceitual para uma lógica do sensível, indo do pensamento ao mito, já que se trata de uma poesia que não deixa intocado nenhum dos extremos, ao mesmo tempo em que não se confunde com eles, pois o seu reino não se identifica de todo com o mito, do qual, no entanto, procede e se alimenta; nem com a filosofia, "embora em sua forma reflexiva o lirismo possa dar a entender que com ela tantas vezes sonha unir-se” (ARRIGUCCI, 2005, p.143).

\section{Poesia, experiência}

Como bem afirma Davi Arrigucci Jr., em Drummond é perceptível a “[...] configuração estética de uma certa ordem da experiência. Lírica e experiência, eis a questão, mas na forma do poema” (2009, p.15). Talvez possamos acrescentar a essa constatação que a configuração estética nos poemas drummondianos, em especial em "O sobrevivente", se assenta sob a ótica de uma (im) possibilidade da experiência:

Impossível compor um poema a essa altura da evolução da humanidade. Impossível escrever um poema - uma linha que seja - de verdadeira poesia.

O último trovador morreu em 1914.

Tinha um nome de que ninguém se lembra mais.

Há máquinas terrivelmente complicadas para as necessidades mais simples.

Se quer fumar um charuto aperte um botão.

Paletós abotoam-se por eletricidade.

Amor se faz pelo sem-fio. 
Não precisa estômago para digestão.

Um sábio declarou a $O$ Jornal que ainda falta muito para atingirmos um nível razoável de cultura. Mas até lá, felizmente, estarei morto.

Os homens não melhoram e matam-se como percevejos.

Os percevejos heróicos renascem.

Inabitável, o mundo é cada vez mais habitado.

$\mathrm{E}$ se os olhos reaprendessem a chorar seria um segundo dilúvio.

("Desconfio que escrevi um poema")

Dedicado a Cyro dos Anjos, "O sobrevivente" se refere a um poema que conseguiu nascer mesmo em meio a um tempo pautado na impossibilidade da experiência, do novo. Note-se que a própria ideia de "compor um poema" contraria o estágio avançado em que se encontra a humanidade: conciliar a prática de compor um poema, nesses termos, soa impossível. São as mesmas constatações observáveis no exemplar de Ana, que grifa o início dos dois primeiros versos ("Impossível compor um poema”, "impossível escrever um poema”), e o último ("Desconfio que escrevi um poema").

A sobrevivência deste poema se dá, então, justamente pelo signo da ironia, pois é enumerando todas as (im) possibilidades de experiência do homem moderno ("máquinas terrivelmente complicadas para as necessidades mais simples", "Se quer fumar um charuto aperte um botão", "Paletós abotoam-se por eletricidade", "Amor se faz pelo sem-fio", "Não precisa estômago para digestão”) que o sujeito lírico segreda ironicamente, entre parênteses: “desconfio que escrevi um poema”. Drummond de fato leva a cabo seu intento, o de corrigir o sentimentalismo com perversidade ${ }^{29}$.

${ }^{29}$ Em entrevista intitulada "Minha vida é simplesmente a única que me foi possível viver", concedida a Martins D'Alvarez e originalmente publicada em A Gaz̧ta, dezembro de 1941, Drummond relata como começou a escrever. Conta que no início começou com "contos, artigo de jornal, crítica impressionista, poemas em prosa - os famigerados poemas em prosa, que tanto me agradavam e nos quais frequentemente introduzia uma piada para corrigir sentimentalismo com perversidade". Um dia, sem perceber, estava fazendo poesias modernistas 
A própria forma enaltece a concepção do poema como "fruto do acaso" ou pelo menos como aparentemente não intencional, pois o ritmo segue o de prosa e a maioria dos versos extrapola os limites da métrica, alguns inclusive bastante extensos, com mais de treze sílabas.

A ironia também aparece na estrofe destacada à direita, com a declaração de "um sábio" a "O Jornal”. O uso intencional dos pronomes indefinidos: "um poema”, "uma linha", "um nome de que ninguém se lembra mais", "aperte um botão", "um sábio” contrasta com uma das poucas definições precisas: "O último trovador morreu em 1914”, ano de início da primeira guerra mundial.

Para a destruição da experiência atualmente não são necessárias catástrofes, como outrora indicou Benjamin, quando já em 1933 havia diagnosticado esta "pobreza de experiência" da época moderna; ao contrário, para nós, hoje, "a pacífica existência cotidiana em uma grande cidade é, para esse fim, perfeitamente suficiente" pois "o homem moderno volta para casa à noitinha extenuado por uma mixórdia de eventos [...], entretanto nenhum deles se tornou experiência” (AGAMBEN, 2005, p.22).

Nesse sentido, Agamben em Infância e História comenta que todo discurso sobre a experiência deve partir atualmente da constatação de que ela não é mais algo que ainda nos seja dado fazer. Pois, assim como foi privado da sua biografia, o homem contemporâneo foi expropriado de sua experiência: “aliás, a incapacidade de fazer e transmitir experiências talvez seja um dos poucos dados certos de que disponha sobre si mesmo" (AGAMBEN, 2005, p.21).

É tendo como fundo esta crise da experiência que a poesia moderna encontra a sua situação própria, pois, observando bem, a poesia moderna não se funda em uma nova experiência, mas em uma ausência de experiência sem precedentes:

no rastro dos Epigramas irônicos e sentimentais, dos poemas de Manuel Bandeira, de Mário e Oswald de Andrade [...]" (ANDRADE, 2011, p.27, grifos meus). 
A experiência é, de fato, voltada primeiramente à proteção contra as surpresas, e o produzir-se de um choque implica sempre em uma brecha na experiência. Fazer experiência de alguma coisa significa: subtrair-lhe a sua novidade, neutralizar o seu poder de choque. Donde o fascínio que a mercadoria e o maquillage - vale dizer, o inexperienciável por excelência - exercem sobre Baudelaire (AGAMBEN, 2005, p.52).

À expropriação da experiência, a poesia responde transformando esta expropriação em uma razão de sobrevivência e fazendo do inexperienciável a sua condição normal, pois numa condição em que o homem foi expropriado da experiência, a criação de um "lugar comum" só é possível mediante uma destruição da experiência.

Esta destruição é, na realidade, a nova morada do homem. O estranhamento, que retira dos objetos mais comuns a sua experimentabilidade, torna-se assim o procedimento exemplar de um projeto poético que visa fazer do "inexperienciável" o novo lugar comum.

\section{(Im)possível Poesia}

Os dois poemas selecionados no recorte desta pesquisa, que partem da leitura realizada por Ana Cristina Cesar, explicitam, em maior ou menor grau, a concepção de um lirismo que passa de uma lógica conceitual a uma lógica do sensível. Por força da memória e da (im)possibilidade da experiência, essa poesia está constantemente por se realizar, já que a procura é sempre incompleta e se realiza sob o signo da indeterminação.

O poeta tenta "explicar" uma sensibilidade em demasia, que o faz dedicar a sua vida à procura da poesia, que o faz tentar materializar a experiência dessa poesia na forma do poema, que muitas vezes "não quer sair". A marca do entrelace dessa busca na vida do poeta, que une experiência e sensibilidade, contudo, inunda a vida inteira.

$\mathrm{Na}$ vida moderna, entretanto, à expropriação da experiência, a própria ideia de “compor um poema” soa impossível. A pergunta talvez não seja, "onde está a poesia”, pois como linguagem, ela é, existe antes do nome, prescinde de significação, ou melhor dizendo, inaugura o próprio sentido.

A questão que se coloca ao poeta moderno talvez seja: como (e por que ainda) materializar a poesia, que existe e ainda pulsa num momento em que não há mais lugar para 
o novo, para o experienciável. A essa pergunta a poesia responde transformando essa expropriação em uma razão de sobrevivência e fazendo do inexperienciável a sua condição normal. Esse panorama, já anunciado no poema "O sobrevivente", é na realidade a nova morada do homem, cujo projeto poético visa fazer do inexperienciável a nova comum(unidade).

\section{DOUBLE READING: CARLOS DRUMMOND DE ANDRADE AND ANA CRISTINA CESAR}

ABSTRACT: Our reading of "Explicação" and "O sobrevivente", two poems of Carlos Drummond de Andrade, part of some notes in a copy of Reunião, book that contains works of Drummond published until 1969, which belonged to the poet Ana Cristina Cesar. In these notes we can observe a notion of poetry allied to life. This notion was very pertinent to the discussions that were being held on the occasion of the "new poets" of the 1970s, which in turn relates to a conception of poetry, perceptible in the selected poems.

KEYWORDS: Ana Cristina Cesar; Carlos Drummond de Andrade; Experience; Poetry.

\section{REFERÊNCIAS}

AGAMBEN, Giorgio. Infância e História: destruição da experiência e origem da história. Trad. Henrique Burigo. Belo Horizonte: Editora UFMG, 2005. - A potência do pensamento: ensaios e conferências. Trad. António Guerreiro. Belo Horizonte: Autêntica, 2015.

ANDRADE, Carlos Drummond de. Obra completa. Rio de Janeiro: José Aguilar Editora, 1967.

. Carlos Drummond de Andrade. Org. Larissa Pinho Alves Ribeiro. Rio de Janeiro: Beco do Azougue, 2011 (Encontros).

2014.

. Nova Reunião: 23 livros de poesia, vol. 3. Rio de Janeiro: Edições BestBolso,

ANDRADE, Carlos Drummond de.; LIMA, Alceu Amoroso. Correspondência de Carlos Drummond de Andrade \& Alceu Amoroso Lima. Org., introdução e notas Leandro Garcia Rodrigues. Belo Horizonte: Editora UFMG, 2014.

ANDRADE, Carlos Drummond de.; ANDRADE, Mário de. Carlos \& Mário: Correspondência de Carlos Drummond de Andrade e Mário de Andrade. Org. Lélia Coelho Frota. Rio de Janeiro: Bem-Te-Vi, 2002. 
ANDRADE, Mário de. Cartas de Mário de Andrade a Prudente de Moraes, neto. Org. Georgina Koifman. Rio de Janeiro: Nova Fronteira, 1985.

- Obra imatura. Coord. Telê Ancona Lopez. Rio de Janeiro: Nova Fronteira, 2013.

ARRIGUCCI JR, Davi. Coração Partido: uma análise da poesia reflexiva de Drummond. São Paulo: Cosac \& Naify, 2002.

Humildade, Paixão e Morte: a poesia de Manuel Bandeira. São Paulo: Companhia das Letras, 2009.

BADIOU, Alain. Pequeno manual de inestética. Trad. Marina Appenzeller. São Paulo: Estação Liberdade, 2002.

BANDEIRA, Manuel. Poesia Completa e Prosa. Rio de Janeiro: Nova Aguilar, 1983.

BENJAMIN, Walter. O conceito de crítica de arte no romantismo alemão. Tradução, introdução e notas Márcio Seligmann-Silva. São Paulo: Iluminuras, 1993.

. Escritos sobre mito e linguagem. Organização, apresentação e notas de Jeanne Marie Gagnebin; tradução de Susana Kampff Lages e Ernani Chaves. São Paulo: Duas Cidades; Editora 34, 2013.

BLANCHOT, Maurice. O espaço literário. Trad. Álvaro Cabral. Rio de Janeiro: Rocco, 1987.

- A parte do fogo. Trad. Ana Maria Scherer. Rio de Janeiro: Rocco, 2011.

CAMARGO, Maria Lúcia de Barros. Atrás dos olhos pardos: uma leitura da poesia de Ana Cristina Cesar. Chapecó: Argos, 2003.

CIPUllo, Sílvia Maria Fernandes. Ana Cristina César lê Drummond. Dissertação. 157 fls. Programa de Pós Graduação em Letras. Universidade Federal de Santa Catarina. Florianópolis, agosto de 1994.

GLEDSON, John. Influências e Impasses: Drummond e alguns contemporâneos. São Paulo: Companhia das Letras, 2003.

HOLLANDA, Heloísa Buarque de. (Org.) 26 poetas hoje. Rio de Janeiro: Editorial Labor do Brasil, 1976.

. Impressões de viagem. CPC, vanguarda e desbunde: 1960/70. Rio de Janeiro: Aeroplano, 2004.

MERQUIOR, José Guilherme. Razão do poema: ensaios de crítica e de estética. $3^{\mathrm{a}}$ ed. São Paulo: É Realizações, 2013.

SCHWARZ, Roberto. A sereia e o desconfiado. Rio de Janeiro: Paz e Terra, 1981.

SÜSSEKIND, Flora. Literatura e vida literária. Rio de Janeiro: Zahar, 1985. 
SISCAR, Marcos. Poesia e crise: ensaios sobre a "crise da poesia" como topos da modernidade. Campinas, SP: Editora da Unicamp, 2010.

WERNECK, Humberto. O desatino da rapaziada: jornalistas e escritores de Minas Gerais (1920-1970). $2^{a}$ ed. São Paulo: Companhia das Letras, 2012.

Recebido em: 08/11/2017. Aprovado em: 29/12/2017. 